\title{
PRODUCTIVISM AND POST-PRODUCTIVISM IN THE OLIVE GROVES OF SOUTHERN SPAIN
}

\author{
José Domingo Sánchez Martínez, Antonio Garrido Almonacid \\ University of Jaén, Andalusia, Spain
}

Manuscript received: December 20, 2016

Revised version: March 14, 2017

\begin{abstract}
Sánchez Martínez J.D., Garrido Almonacid A., 2017. Productivism and post-productivism in the olive groves of southern Spain. Quaestiones Geographicae 36(2), Bogucki Wydawnictwo Naukowe, Poznań, pp. 57-69, 6 tables, 3 figs.

ABSTRACT: This work examines changes in the cultivation of olive groves in the region of Andalusia since the accession of Spain to the European Common Market (1986). The first phase is marked by the triumph of productivism in which some of the basic elements of this model (specialisation and intensification) are overwhelming, according to the statistical sources used for this research, although the behaviour in terms of corporate concentration can be considered unique. Also notable, as we will explain later, are other less desirable effects of the process, which can currently be considered environmentally unsustainable. As the weaknesses and contradictions of the model have become evident, in the recent years - as a result of the new stimuli provided by the Common Agricultural Policy - more attention is paid to the opportunities offered by rural development. For the moment, the results of this approach have been limited, although the 2015-2020 planning period could be decisive for its reorientation.
\end{abstract}

KEY WORDS: Common Agricultural Policy, olive oil, rural development, monoculture, southern Spain.

Corresponding author: José Domingo Sánchez Martínez, Departamento de Antropología, Geografía e Historia, Facultad de Humanidades y Ciencias de la Educación, Edificio D-2, Universidad de Jaén, Campus de Las Langunillas s/n, 23071 - Jaén, Spain; e-mail: jdsanche@ujaen.es

\section{Introduction}

The role of woody crops in the Mediterranean is explained by their ability to overcome the difficulties imposed by summer aridity. The hardiness of plants such as the fig tree, the almond tree, the grapevine or the olive tree has allowed, in fact, the agricultural colonisation of areas of very limited agricultural capability. In the pre-industrial agricultural model, these crops were rarely introduced in the most fertile soils, which were reserved for the production of cereals, fruits and vegetables (the latter two associated with irrigation). This did not impede the existence of export-oriented plantations, as in the prominent case of wine and oil, renowned since antiquity as elixirs of the south, but they were always limited to very localised enclaves, until the industrial revolution universalised cheap transport (Silva et al. 2016).

The progressive globalisation of the economy has profoundly altered these guiding principles in the allocation of land use and the orientation of the resource management systems. In particular, olive groves have not stopped expanding and intensifying since the mid-19th century, in response to the growth in both, the population and the consumption in areas close to its production, as well as, especially, the ability to export increasing volumes to more destinations. 
Globally, the area occupied by this plant has increased fivefold since 1961 to reach over 11 $\mathrm{M}$ ha in the 47 countries where it is currently grown (Consejo Oleícola Internacional 2015). Although there have been expansions outside its original area (Australia, China, South Africa and Argentina), the dominant locations are still the traditional regions, those in which the largest growth in area and production have been concentrated. Of those, the case of the region of Andalusia is spectacular, especially when one considers that the stake of the majority of farmers, unlike what might happen in Italy or France, has been the optimisation of all the processes of agricultural modernisation, so that on Andalusian farms the most canonical elements of productivism are easily recognisable. Currently, vine cultivation occupies more than $1.5 \mathrm{M}$ ha, equivalent to a third of the European olive groves, and has the capacity to produce $40 \%$ of the oil and $20 \%$ of the olives obtained worldwide (Junta de Andalucía 2011).

To a large extent, this process is related to the accession of Spain to the European Common Market (1986). In fact, in the two decades prior to this milestone, the Spanish olive grove went through a critical period since the low profitability resulted in the uprooting of olive trees across the country, an issue which came to be regarded as a "cultivation problem", and which encouraged the government, under the circumstances, to implement a programme of restructuring and modernisation of production which was in force between 1972 and 1988 (Guzmán Álvarez 2005). The results of this programme were quite modest compared with what would happen when the producers could benefit from the $\mathrm{CAP}$, even though the intensification, coupled with indifference and a lack of knowledge of the markets, eventually turned against the interests of primary producers (Delgado Cabeza 2014). To this must be added problems of the economic sustainability of the sector, which in this case has some special territorial implications because the olive tree is dominant (often a monoculture) in a high proportion of the municipalities in the region. In these circumstances, without lacking initiatives "from below", the reaction is led by the regional government and linked to the compliance with the provisions of its rural development programme for the period 2016-2020.
One of the objectives of this paper, after analysing the terms of the intensification of production, is specifically to carry out an estimation of the changes resulting from the application of different principles in the search for competitiveness by reducing costs, assessing the impact they have in terms of changing the conventions and mentalities hitherto dominant. Our overall aim is, therefore, a modest attempt to contribute to the fruitful debate on the coexistence of strategies of modernisation and rural development in the transformation of European agriculture in the recent decades (Evans 2001; Van der Ploeg, Roep 2002). Although for some authors it is all about successive stages, the truth is that post-productivism is a debatable paradigm and in any case it is limited to developed regions under the intense flow of the surrounding urban areas in northwestern Europe (Almstedt 2013; Torre 2015; Van Broekhuizen et al. 2015). In the case of southern Europe, in fact, it has been shown that the dominant pattern is clearly inspired by the productivist rationality, not only in the olive grove but also in sectors such as intensive fruit and vegetable horticulture, stabled livestock, or the vineyard (Moreno-Pérez 2013; Ruiz Pulpón 2013).

\section{Territory and context: the CAP and the olive grove in Andalusia}

The Autonomous Community of Andalusia covers an area of $87,258 \mathrm{~km}^{2}$ and has a population of 8.4 million (2015). With almost $41 \%$ of its territory set aside for agricultural production, the olive grove is by far the main land use. Spatially, they are concentrated in the inland areas, all of which make up the province of Jaén and the other neighbouring provinces of Cordoba and Granada. In fact, as we expand the scale, regional specialisation is more obvious (Table 1). In all cases there is, however, a preference for oil production and, for the moment, the predominance of the rain-fed system.

The evolution of this sector affects the region as a whole to such an extent that a few years ago a specific law for this crop was passed in order to ensure the sustainable development of the specialised areas. As was reflected in the preamble of this law, "it is the main activity of more than three hundred Andalusian towns in which more than two 
Table 1. Importance of olive cultivation at the national, regional and provincial (Jaén) scales in 2014 (area in hectares).

\begin{tabular}{|l|c|c|c|}
\hline & Spain & Andalusia & Jaén \\
\hline Geographical area (a) & $50,554,437$ & $8,720,589$ & $1,349,609$ \\
\hline Cropland (b) & $17,132,780$ & $3,559,919$ & 656,156 \\
\hline Olives for oil & $2,343,184$ & $1,442,598$ & 583,319 \\
\hline Table olives & 163,795 & 98,511 & 198 \\
\hline Total olive groves (c) & $2,506,979$ & $1,541,109$ & 583,517 \\
\hline Rain-fed olive groves & $1,900,832$ & $1,020,473$ & 310,929 \\
\hline Irrigated olive groves (d) & 606,147 & 520,636 & 274,588 \\
\hline \% b/a & 33.89 & 40.82 & 48.62 \\
\hline$\%$ c/b & 14.63 & 43.29 & 88.93 \\
\hline$\%$ d/c & 24.18 & 33.78 & 47.06 \\
\hline
\end{tabular}

Source: Ministerio de Agricultura, Alimentación y Medio Ambiente (last accessed 20/07/2016). http:/ / www.magrama.gob.es/es/estadistica/temas/publicaciones/anuario-de-estadistica.

hundred and fifty thousand families of olive farmers live, and provides more than twenty-two million days of work a year" (Junta de Andalucía 2011). No less remarkable is the olive sector from the agribusiness perspective, because it consists of more than 800 oil mills and 200 table olive production plants, nearly 700 oil bottlers, 40 olive-kernel oil producing plants, 15 refineries and 15 establishments engaged in the production of energy from by-products derived from the milling of olives (Junta de Andalucía 2014).

To understand how it has come to this situation, which has been developing since the late 19th century, we must notice the decisive effect of the Common Agricultural Policy (CAP), one of the most obvious practical embodiments of the process of building the European Union. Its objectives and principles, established in the 1950s, painted the first picture with clearly productivist and protectionist overtones. One can then speak of the existence of an economic focus in which the rural environment is, before anything else, a support for some agricultural activities in a permanent state of modernisation. The adoption of the Agenda 2000 introduced a more territorial vision, promoting a model of multifunctional agriculture that, in addition to maintaining its economic competitiveness, was environmentally sustainable, generating quality products and the ability to create jobs and wealth for those who maintain the social fabric of the rural communities (Parra Lopez, Sayadi Gmada 2009).

As it could not be otherwise, this evolutionary framework of the CAP is perfectly recognisable in the olive groves. Since 1966, the support was based on a price system where institutions played an active role, highlighting the mechanism to ensure the profitability of the producers when the market remunerated them below a certain threshold. This intervention price may be considered one of the institutions most deeply ingrained in the mentality of Spanish olive growers when they accessed the European Common Market; but no less important was the welcome given to the generous aid scheme for production introduced in the late 1970s. As much as the expansion to the south of the following years would imply a limitation on the amount of such aid and the fact that Spain accepted a long transitional period to fully benefit from all the expected benefits, the framework (in which assistance was also contemplated for consumption and a system of tariff protection) opened a phase of extraordinary expansion and intensification of cultivation. Assured of selling the whole production at a profit, and encouraged to increase it in order to receive more aid, this behaviour is not surprising. However, the model had a number of notable weaknesses, the lack of a market orientation and a disregard for the environmental effects of intensification among them.

The 2004 reform of the Common Market Organisation (CMO) in the sector was, in line with the proposals of the Agenda 2000, a profound transformation that began with the amendment of the assistance scheme, thereafter decoupled from production (the single payment scheme) and linked to the fulfilment of certain environmental measures. Given the existing disparity in the holdings as a function of different geographical and economic factors in each case, and so as not to provoke a significant transfer between 
territories, the calculation of this aid was made from the average production figures obtained during the 1999/2000 and 2002/2003 seasons. Meanwhile, the instrument of intervention was abolished, giving way to a private storage mechanism that has only been put into operation in exceptional situations. This policy of markets and aid has been supplemented since 2007 with rural development measures, after the consideration of the second pillar of the CAP reached the policy level. During the 2007/2013 programming period, for example, assistance to integrated production in particularly sensitive areas and the promotion of organic olive groves were emphasised (San Miguel Tabernero 2010).

In October 2011 the European Commission presented its first proposal documents for a new modification of the CAP, which was regulated in 2013. In the words of the then Commissioner, the intention was to deepen what had been started years earlier in terms of environmental and economic sustainability (Velasco et al. 2012). Among the decisions resulting from the development of the legislation in Spain, the adoption of a new form of direct aid to farmers should be highlighted. Initially, it was intended to provide a sort of flat tariff per area, to which would be added a quantity towards green assistance for making commitments to the climate, environment and crop diversification. However, these initial assumptions clashed strongly with the interests of the sector, since they were not sufficiently big to cover the large number of holders of entitlements generated in the past, nor were they reasonable for addressing the huge disparities, both geographical and in terms of the agricultural holdings, that could be verified in the territory. Nor did the sector understand the need to diversify production in order to justify receiving the green payment for a woody crop in which small-scale and part-time farming is common.

The fact is that, in the end, the need to diversify crops was removed, a system for the distribution of a basic payment that does not fundamentally alter the existing balance was developed, and it was agreed that the green payment would be a percentage of the basic payment. In truth, the total amount of funds available for such assistance under the first pillar has been reduced, so that the rural development programme contemplated for the sector takes on greater prominence (Sánchez et al. 2015).

\section{Effects of productivist stimulation}

Through various related aspects, we can date the transformative effect that the CAP has had on Andalusian olive groves. The first is large regional specialisation. As shown in Table 2, not only can a frenetic rate of growth be observed starting from the early 20th century, but compared with the greater previous spatial dispersion, olive groves are becoming more and more concentrated in this region, a trend, moreover, that seems to have stagnated since the beginning of this century. In any case, the absolute and relative growth in the 1986-1999 period reflects the immediacy and depth of change brought about by the CAP.

Thus, in addition to the existence of very favourable soil and climate conditions for the tree (Ministerio de Agricultura 1975), some very powerful political and economic reasons were added, thereby triggering this growth. The expansion, through the process of substitution of arable crops mainly on rain-fed land - although there have been no lack of examples of the expansion of the agricultural frontier onto forested land - has changed the usual pattern of the geographical location of the olive groves, mostly by occupying low- or medium-grade land, but was also found to be colonising the most fertile land, a fact that can be seen very well if we compare the distribution of olive groves in relation to the capacity of land use at different times (Paniza et al. 2015). In fact, at the provincial level, since 2000 there has been a shift in new plantations to the western portion of the region, especially in the province of Seville, which has welcomed

Table 2. Increase in and concentration of the area (ha) of the Spanish olive grove in Andalusia, 1900-2015.

\begin{tabular}{|c|c|c|c|}
\hline Year/ period & Andalusia & Spain & $\%$ \\
\hline 1900 & 711,599 & $1,197,000$ & 59.45 \\
\hline 1931 & 969,069 & $1,911,000$ & 50.71 \\
\hline 1955 & $1,118,395$ & $2,129,867$ & 52.51 \\
\hline 1977 & $1,200,022$ & $2,084,365$ & 57.57 \\
\hline 1986 & $1,232,018$ & $2,099,052$ & 58.69 \\
\hline 2000 & $1,489,700$ & $2,405,837$ & 61.92 \\
\hline 2014 & $1,549,967$ & $2,515,807$ & 61.61 \\
\hline$\Delta 1986-2014$ & 317,949 & 416,755 & 76.29 \\
\hline$\Delta 1986-2014(\%)$ & 37.92 & 31.60 & - \\
\hline$\Delta 1900-2014$ & 838,368 & $1,318,807$ & 63.57 \\
\hline$\Delta 1900-2014(\%)$ & 117.81 & 110.18 & - \\
\hline
\end{tabular}

Source: Zambrana Pineda (2006) and Anuario de Estadística Agraria. 
Table 3. Evolution in the surface area planted with olive groves (ha) in Andalusia by provinces, $1986-2014$.

\begin{tabular}{|l|c|c|c|c|c|c|}
\hline & 1986 & 1999 & 2014 & $\Delta 1986-1999$ & $\Delta 1999-2014$ & $\Delta 1986-2014$ \\
\hline Almeria & 9,858 & 15,500 & 20,305 & 5,642 & 4,805 & 10,447 \\
\hline Cadiz & 19,450 & 20,061 & 23,148 & 611 & 3,087 & 3,698 \\
\hline Cordoba & 294,594 & 344,874 & 347,107 & 50,280 & 2,233 & 52,513 \\
\hline Granada & 114,800 & 172,233 & 186,647 & 57,433 & 14,414 & 71,847 \\
\hline Huelva & 31,442 & 30,266 & 32,921 & $-1,176$ & 2,655 & 1,479 \\
\hline Jaén & 474,175 & 562,761 & 585,113 & 88,586 & 22,352 & 110,938 \\
\hline Malaga & 107,699 & 120,782 & 130,826 & 13,083 & 10,044 & 23,127 \\
\hline Seville & 180,000 & 188,176 & 223,900 & 8,176 & 35,724 & 43,900 \\
\hline Andalusia & $1,232,018$ & $1,454,590$ & $1,549,967$ & 222,572 & 95,377 & 317,949 \\
\hline Spain & $2,099,052$ & $2,364,614$ & $2,515,807$ & 265,562 & 151,193 & 416,755 \\
\hline
\end{tabular}

Source: Anuario de Estadística Agraria (last accessed on 20 May 2015) (http:/ /www.magrama.gob.es/es/estadisti$\mathrm{ca} /$ temas/publicaciones/anuario-de-estadistica).

intensive and super-intensive plantations in well-sized and well-capitalised operations, with the best agronomic conditions and designed to be profitable even in case of the disappearance of community assistance (see Table 3). In any case, the province of Jaén is the one that has attracted the greatest expansion in area since 1986.

In addition to the geographical expansion and the occupation of prime agricultural land, the increase in yields is also a result of intensification.
The systematic use of fertilisers, the mechanisation of labour, the greater care given to the plants, or an increase in the number of trees per area are among the actions that encourage this process, which has been described as a productivity revolution (Berbel, Giannocaro 2013). But the most important factor responsible for increasing yields is undoubtedly irrigation. Traditionally, the olive tree has been considered a rain-fed crop and, therefore, long periods were needed for the tree

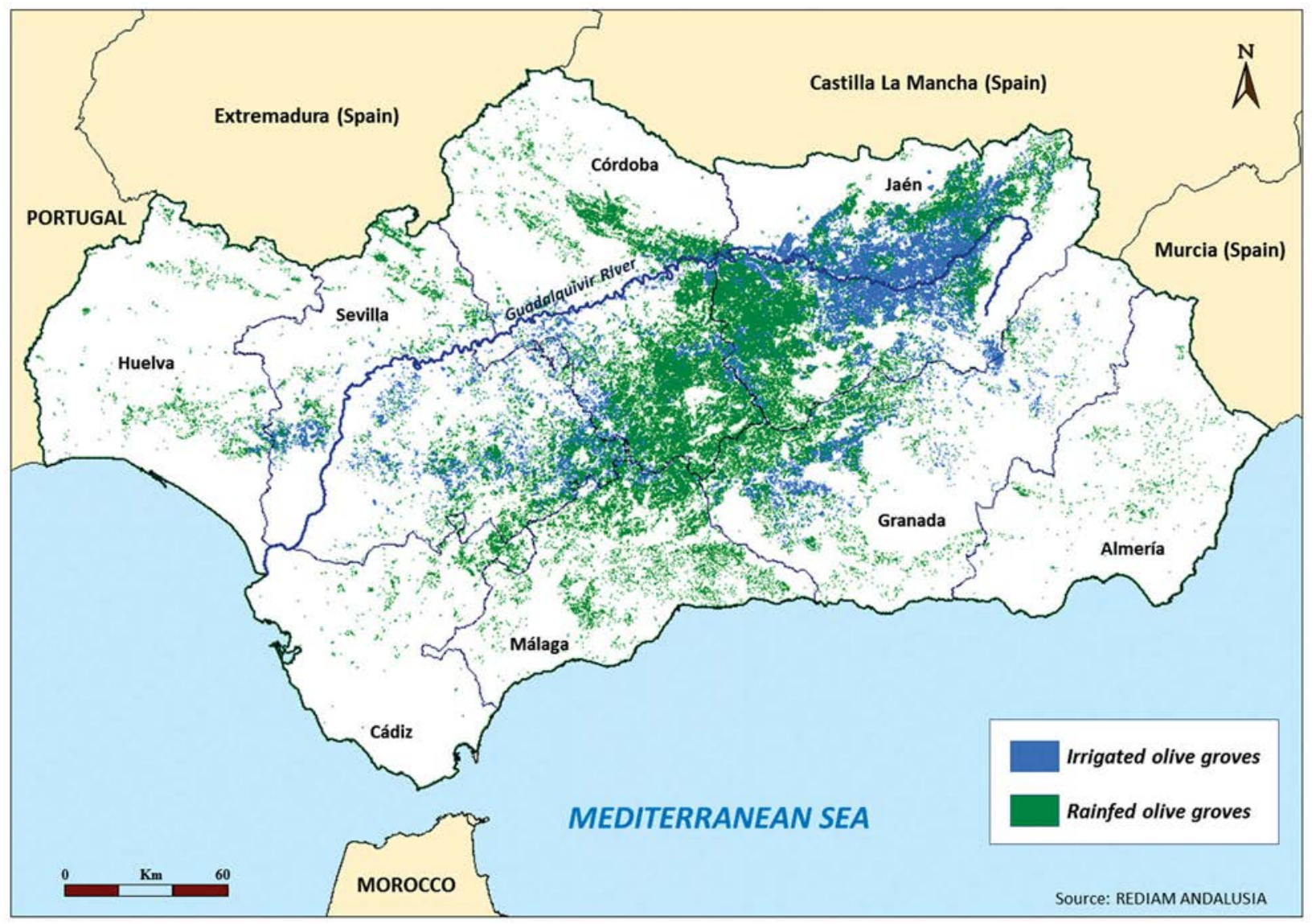

Fig. 1. Irrigated olive groves in the Guadalquivir river basin (Andalusia, 2011). 
Table 4. Index of the concentration of the production of Spanish virgin olive oil (tonnes) in Andalusia and the importance of that obtained in Jaén compared with Andalusia during the period 2005-2014.

\begin{tabular}{|c|c|c|c|c|c|}
\hline Year & Jaén (a) & Andalusia (b) & Spain (c) & \% a/b & $\%$ b/c \\
\hline 2014 & 228,482 & 669,935 & 839,788 & 34.11 & 79.77 \\
\hline 2013 & 751,610 & $1,474,064$ & $1,765,248$ & 50.99 & 83.50 \\
\hline 2012 & 140,737 & 472,578 & 652,687 & 29.78 & 72.40 \\
\hline 2011 & 678,472 & $1,326,522$ & $1,395,210$ & 51.15 & 95.08 \\
\hline 2010 & 585,942 & $1,138,052$ & $1,567,523$ & 51.49 & 72.60 \\
\hline 2009 & 567,438 & $1,167,040$ & $1,384,383$ & 48.62 & 84.30 \\
\hline 2008 & 431,382 & 831,866 & $1,044,687$ & 51.86 & 79.63 \\
\hline 2007 & 494,548 & 988,677 & $1,185,917$ & 50.02 & 83.37 \\
\hline 2006 & 489,819 & 924,620 & $1,092,602$ & 52.98 & 84.63 \\
\hline 2005 & 265,610 & 638,450 & 820,597 & 41.60 & 77.80 \\
\hline Average & 463,404 & 963,180 & $1,174,864$ & 48.11 & 81.98 \\
\hline
\end{tabular}

Source: Anuario de Estadística Agraria (http://www.magrama.gob.es/es/estadistica/temas/publicaciones/anuario-de-estadistica).

to go into production and with meagre and very irregular harvests, as well as the wet and dry cycles characteristic of the Mediterranean climate. However, the increase in the irrigated area in the recent years has enabled harvests not only to grow, but also to be regularised with very similar production levels each season.

In fact, in 1986 only $7.13 \%$ of the Andalusian olive groves were irrigated, while in 2014 it was already $33.75 \%$ (523,171 ha), mostly with modern drip irrigation systems. Accordingly, although allocations per unit area are low compared with other irrigated crops (below 1,500 $\mathrm{m}^{3} / \mathrm{ha}$ ) and some plantations even resort to deficit irrigation employing a quantity of water significantly lower than the previous one, but used at critical times in the phenological cycle of the plant, the olive tree has become the number one consumer of water in the river basin of the Guadalquivir, as shown in Fig. 1.

Yet, despite these man-made contributions, climate variability is still an important factor to take into account as far as the annual production is concerned, as can be seen in the 2005-2014 data shown in Table 4 . However, the most notable fact is that Andalusia produces an average of almost $82 \%$ of Spanish olive oil, a clear sign of yields that clearly exceed those that should be expected given the area data we have commented on above (Table 2). It is evident, therefore, that Andalusian olive groves are much more productive than those found in other regions of Spain.

We have again incorporated data from Jaén province as the most palpable case of the creation of a true monoculture. Fig. 2 presents the evolution of the last 45 years showing the significant increase in harvests since 1996, i.e. with the start of the new productivist plantations sponsored by the CAP.

The third aspect of productivism is corporate concentration. This has not been observed, however, either in the average size of farms, which remains markedly small ${ }^{1}$ (8.02 ha, with almost $60 \%$ of farms under 5 ha, according to the Agricultural Census 2009, the last published), or in the processing industry of olives. This is quite contrary to what happens with regard to the intra-industry demand, where a very small number of large bottling and distribution companies dominate the market for olive oil (Rodríguez, Parras 2011). The lack of knowledge and action in the olive-oil value chain on the part of farmers (this does not happen much in the case of table olives) is one of the factors that explains why during the period 2005-2012 oil olive was the only major category of European agriculture to suffer a reduction in prices, a situation which added to the increase in production costs, resulting in an exceptionally dangerous situation for specialised olive-growing territories (AEMO 2010).

Moreover, environmental problems arising from the intensification of a production-driven agricultural policy are widespread and profound: increased erosion, pressure on the quantity and quality of water resources, loss of biodiversity, to name some of the most important ones (Sánchez

Among the reasons that explain the maintenance of this ownership structure can be attachment to the land and the spread of part-time farming. 


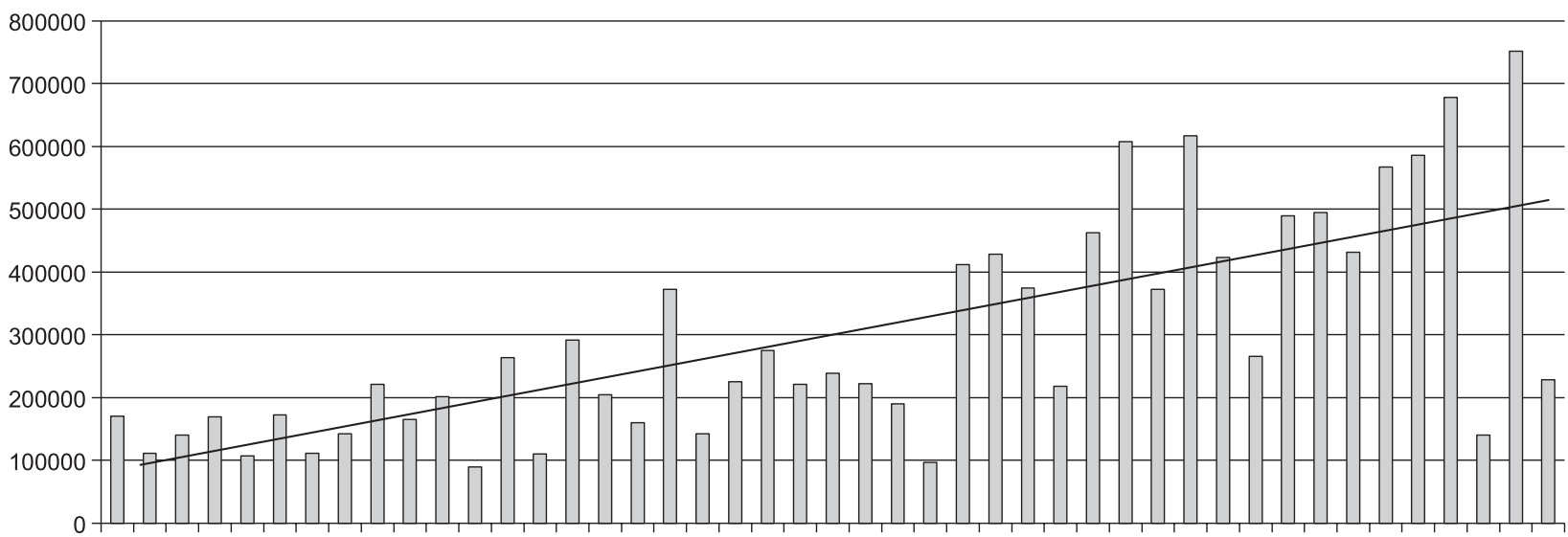

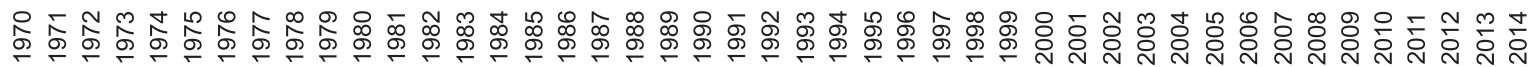

Fig. 2. Production of virgin olive oil (tonnes) in the province of Jaén, 1970-2014.

Source: Ministerio de Agricultura, Alimentación y Medio Ambiente (last accessed on 23/07/2016). http://www.magrama.gob.es/es/estadistica/temas/publicaciones/anuario-de-estadistica.

Table 5. Distribution of Andalusian olive groves by yield (the 2009-2010 season).

\begin{tabular}{|l|c|c|c|}
\hline \multicolumn{1}{|c|}{ Type } & Area (ha) & $\%$ & Yield (kg olives/ha) \\
\hline Olive groves with low yields & 95,923 & 6.30 & 431.25 \\
\hline Olive groves with steep slopes & 354,515 & 23.30 & $3,355.73$ \\
\hline Olive groves - extensive with fewer than 150 trees/ha & 723,018 & 47.51 & $3,967.49$ \\
\hline Olive groves - extensive with medium density & 113,629 & 7.47 & $4,111.80$ \\
\hline Olive groves - intensive & 213,361 & 14.02 & $4,831.56$ \\
\hline Olive groves - super-intensive & 21,375 & 1.40 & $6,170.80$ \\
\hline Total & $1,521,821$ & 100.00 & $3,764.95$ \\
\hline
\end{tabular}

Source: Junta de Andalucía 2014.

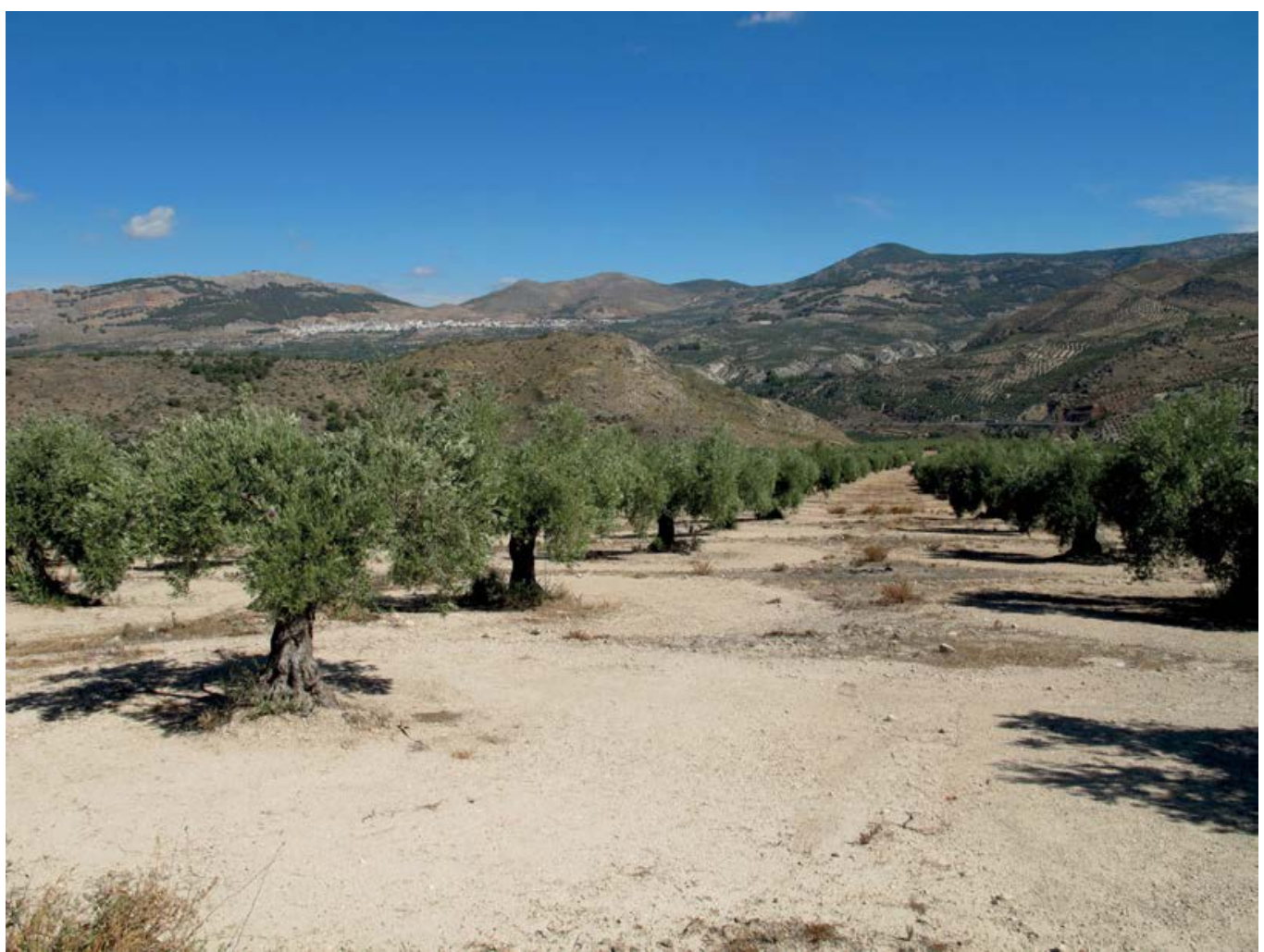

Photo 1. Marginal olive grove (photo: José D. Sánchez Martínez). 


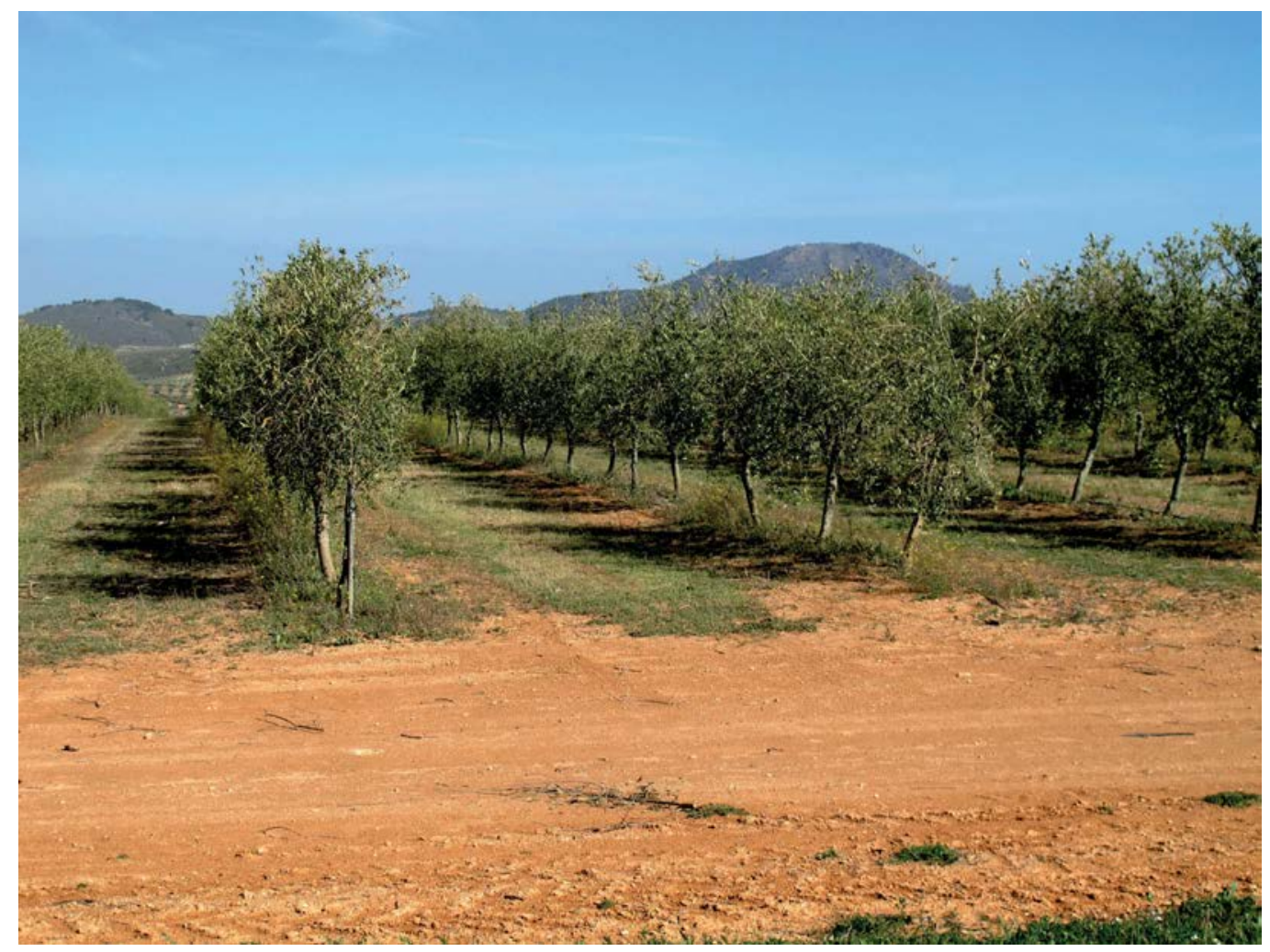

Photo 2. Intensive olive grove (photo: José D. Sánchez Martínez).

et al. 2008). While this reality was used as an argument in the reorientation of the CAP in the last decade (Beaufoy 2001), it should be noted that environmental conditionality for the collection of the aid has been very lax, unable in any case to decisively reverse the criticism plaguing monoculture. The most worrying fact of all, no doubt, is the high rate of erosion, which affects more than a half of the cultivated area at different levels of severity. In fact, high and very high losses (especially those above $50 \mathrm{t} /$ ha/year) were observed in $23 \%$ of the land dedicated to this type of agriculture (Junta de Andalucía 2014). Moreover, olive groves managed using organic methods are rare, with scarcely 58,000 ha by the end of 2014 (3.7\% of the total). Meanwhile, more encouraging results are offered by an integrated production management system halfway between conventional and ecological methods, which is practised on 396,000 ha $(25.55 \%)$.

One final aspect we want to touch on is the enormous economic variability of agricultural operations that coexist nowadays. Arising in changing economic and technical contexts and spread over contrasting eco-geographical environments, production results can be shockingly different: in the olive groves in marginal rain-fed mountain areas it is not unusual to harvest scarcely $500 \mathrm{~kg}$ of olives per hectare per year on average; in contrast, on the most modern plantations with espaliers, this amount can be multiplied by thirty or more. However, for the moment, most farms $(77.11 \%$ of the area) have yields lower than $4,000 \mathrm{~kg} / \mathrm{ha}$ (Table 5), a threshold that can perfectly distinguish olive trees according to their economic viability and clearly visible on a simple tour of plantation areas (Photos 1 and 2).

\section{At the beginning of change: concentric differentiation and diversification}

The Andalusian olive grove specialises in the production of commodities, especially in the case of olive oil, a barely differentiated product sold in bulk, operating in large volumes, and one that consumers purchase without unduly worrying about the place of origin or the quality. This competitive strategy based on reducing production costs generates, of course, significant weaknesses and threats.

At the moment, the processes of relocation taking place in favourable locations on all continents (such as in South America or some parts 


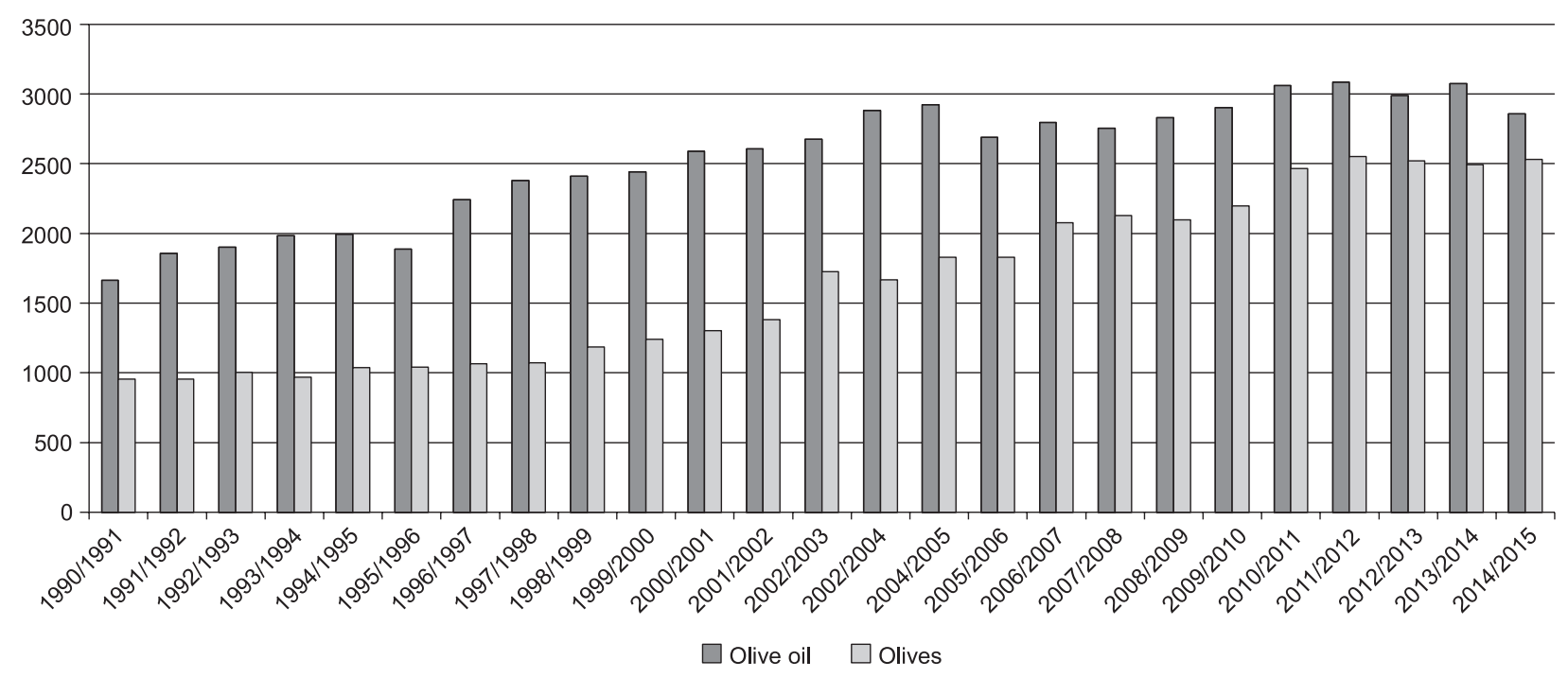

Fig. 3. Evolution of the global consumption of olives and olive oil, 1990-2015.

Source: International Olive Council (last accessed on 25/07/2016) (http://www.internationaloliveoil.org/estaticos/ view/130-survey-and-assessment-divisionn).

of China) are not decisive in quantitative terms. However, in all the non-EU Mediterranean countries programmes are being developed to expand and intensify olive groves, trying to gain a comparative advantage derived from some costs in the factors of production being significantly lower than those achieved in the European Union². To a certain extent, this situation compromises the future of the Spanish producers, who have sought and obtained financial support from the regional administration for the uprooting of the least productive olive trees in order to copy the new designs of denser planting that, even though they do not involve notable production increases, do entail a considerable reduction in production costs, especially by dramatically saving on the need for labour. Obviously, only part of the territory has the conditions needed for such changes, since the physiographic, financial and structural requirements are very demanding (Sánchez, Gallego 2011).

Moreover, this new process of technical modernisation would not eliminate some of the most significant obstructions we have described above, such as those deriving from the model of intensive management of natural resources (requiring more water, for example), or those related to

2 One of the most notable examples is Morocco, which in the last six years has doubled its production until becoming the fifth largest global producer; http:// www.olimerca.com (last accessed on 15/09/2016). the existence of a value chain in which primary producers play a minor role. More complex and global strategies are therefore put forward, such as that established in the Rural Development Programme to which we will refer later.

A number of circumstances may favour this radical change. First, a net increase in the global demand for olive products is observed. In the case of oil, although it represents a tiny amount compared with all the vegetable fats consumed in the world (no more than 3\%), consumption has almost doubled in the last 25 years. Moreover, among the countries that matter most outside the Mediterranean area in absolute terms (the USA, Brazil, Germany, the United Kingdom, China, Canada and Russia), per capita consumption is still negligible, the most notable example being Canada with scarcely $1 \mathrm{~kg}$ per year, generating expectations of a very promising future. And more spectacular has been the case of table olives, which in the same period has seen an increase in consumption by almost a factor of three (Fig. 3).

It is obvious, therefore, that the market rapidly absorbs the output, and thus the strengthening of specialised areas and the aspirations of new areas in order to obtain more significant yields are logical. Behind this behaviour there are different demographic, economic and commercial factors, but also cultural ones, in particular the recognition of the Mediterranean diet as the Intangible Cultural Heritage of Humanity (Rastoin 2016). It is paradoxical, however, that the health benefits 
of these products are praised while their obtainment has seriously harmed the health of the ecosystem (Scheidel, Krausmann 2011). It is obvious that producers must be capable of dealing with these contradictions if they want to target the latest market trends, something that so far they have not worried about given the productivist context in which they were immersed and which we have previously noted.

The obsession with quantity is therefore the first and most important condition to transform, an issue that has been repeatedly raised over the past forty years. In fact, in the late 1970s, the first two regulatory boards for the protected denominations of olive oil had already begun to operate $^{3}$, to which was added another one, dedicated exclusively to table olives. However, the overall results of their operation, which are located in almost all cases in unfavourable farming areas (mountain olive groves), have proved modest. This is not only due to the lack of price spreads that are significantly higher than those obtained in other production areas without the distinction of territorial quality, but also because of the low percentage of production marketed under this label, which can be $25 \%$ of the total production (Junta de Andalucía 2014). Much smaller, of course, is the quantity packaged and finally sold by the companies belonging to the Protected Designation of Origin (POD). However, it can be concluded that it has helped significantly to increase the percentage of graded oil, something possible only with the universalisation of more careful cultivation practices and the treatment of the fruit in the processing plants. Nevertheless, the economic and environmental results are still far behind those that could be achieved through these institutions (Angles et al. 2013; Belletti et al. 2015).

The message of quality has also taken hold by other means. In particular, one decisive aspect has been the existence of national and international awards, a mechanism that, although showing signs of saturation and exhaustion, has proved ideal for small private oil mills (first) and large cooperatives (later) to significantly improve the percentage of higher-quality oil (extra virgin)

http:/ / www.esenciadeolivo.es/aceite-de-oliva/ aceite-de-oliva-en-espana/denominaciones-de-origen-de-andalucia (last accessed on 25/07/2016). obtained. It is an affordable and highly effective means of promotion for those who are granted this recognition. This commitment has meant tearing down one of the most established and, as has been shown, harmful traditions, that of delaying the collection of the fruit until almost the beginning of winter. On the contrary, it is common now that the harvest begins in early October, when the fruit offers lower industrial yields but better conditions for maintaining its organoleptic and health properties. The most important thing is that this step puts primary producers in the mind-set of making progress in the stages that add value to their goods: packaging and marketing/direct export (Rodríguez et al. 2017).

More advanced innovators implement strategies that now combine concentric diversification and differentiation. Sometimes this involves a radical change in the way we understand the manufacturing process of olive products. ${ }^{4}$ Oil comes from the grinding of olives and the subsequent separation of the usable fraction. However, current technology allows a complete deconstruction of the fruit, so that each of the component parts can be initially separated: skin, flesh, pit and seed. From these components, as well as from the olive leaves that fall during the harvesting of the fruit, almost twenty products are obtained for food, cosmetics, pharmaceuticals and construction, but also for energy (biomass) and fertilisers. Olive oil is, therefore, one more product obtained and, in fact, there are two types that are marketed, one from the pulp and the other extracted from the seed, whose properties make it especially interesting for pharmaceutical uses. The only company that has currently opted for this way of working is also an example of a search for new markets in different cultural contexts of the Mediterranean, trying to combine the healthy qualities of the oil with the taste of the fats that are usually consumed in such places, by adding tiny portions (about $1 \%$ ) of soy or butter, specially designed for children's consumption (a strawberry, orange or chocolate flavour), or for the seasoning of salads (flavoured with garlic, basil or chilli).

Of course, the equipment and functioning of an olive-oil mill that is technologically adapted

\footnotetext{
4 http://www.grupoelayo.es (last accessed on 26/07/2016).
} 
to these processes does not look at all like a traditional industry. The change in these operations, considering that many participate in the conservative strategy that stems from their status as processing and marketing cooperatives, is currently utopian, since hardly any are now found assimilating options deriving from the improvement in oil quality (Rodríguez et al. 2017).

In addition to the production of food and other commodities, farmers (often encouraged by the public administration) have also shown interest in acknowledging and developing capabilities that go beyond the strictly agricultural nature of the olive grove, such as the environmental, landscape, tourist and heritage factors. In the context of concern for sustainability, these aspects of multifunctionality become more and more critical (Parra, Sayadi 2009), although their development has lagged behind other territories and cultures that long ago discovered the importance they have for their viability. And all of this has triggered the need to first develop a product of excellent quality. The paradigmatic example of this is what has occurred with some of the wines with the most famous denomination of origin in the world, but also with small olive-oil producing zones in countries like France or Italy, where obtaining large volumes has never been a concern (Cohen et al. 2012). In the context of the productivist and bulk-oriented monoculture of southern Spain, one can understand the reason for the slowness and modesty with which these new approaches have been welcomed, as well as the enormous potential that are forecast for their launch, given the cultural stockpile that this involves, its size and internal diversity, or the significant support that public institutions provide.

Policy guidelines in this regard are decisive. Thus, in the Rural Development Plan for the current programming period of the CAP, special attention is paid to improving the environmental conditions of the crop (Table 6), thereby recognising one of the largest deficiencies that currently exists, as well as the complexity that results from the climatic changes in which we are immersed, an aspect about which there is still little awareness of the effects that may occur. Another important item is organic olive growing, although the increase in the area intended to benefit from this formula for subsidised production by 2020 is very small $(7,865$ ha). In fact, it seems that the purpose is mainly to maintain the current area in the face of repeated cases of abandonment that these crops experience, caused, among other things, by the bureaucratic complexity that is often impossible for non-professionalised smallscale farmers to navigate.

Another great choice for territorial revaluation that has been solidifying in the recent years is the generation of a new tourist product under the specific name of "oleotourism" (LópezGuzmán, González-Fernández 2011). As in the case of wine, obtaining oils of high quality has led to the expansion of the gastronomic culture related to the product, but also to a growing interest in its history, the associated heritage and the territory where it is obtained. Therefore, museums and other exhibition spaces become more widespread, where the most diverse aspects of the culture of the olive grove and oil (ethnological, economic, industrial, monumental, environmental,

Table 6. Planned expenditure, by measure, in the 2014-2020 Rural Development Programme of Andalusia (thematic sub-programme of the olive sector).

\begin{tabular}{|l|c|c|}
\hline \multicolumn{1}{|c|}{ Measure } & Cost $(€)$ & Cost (\%) \\
\hline Knowledge transfer and training & $4,628,376$ & 1.52 \\
\hline Advisory services & $6,462,621$ & 2.12 \\
\hline Quality promotion & $3,729,728$ & 1.23 \\
\hline Investment in physical assets & $115,701,274$ & 38.03 \\
\hline Creating producer groups and organisations & $1,678,378$ & 0.55 \\
\hline Agro-environment and climate & $94,139,304$ & 30.94 \\
\hline Organic agriculture & $72,290,520$ & 23.76 \\
\hline Co-op & $5,594,591$ & 1.84 \\
\hline Total & $304,224,792$ & 100.00 \\
\hline
\end{tabular}

Source: Junta de Andalucía and Gobierno de España (http://www.juntadeandalucia.es/organismos/empleoempresaycomercio/areas/economia/fondos-europeos/paginas/programacion-fondo-agricola.html) (last accessed on 22/07/2016). 
etc.) are collected and presented. Other resources that fuel this tourist activity include visiting oil mills, participating in the harvest of the fruit, gastronomic tasting events with olive products, touring on thematic routes, admiring the scenery, or staying in rural facilities embedded in an olive-producing area. And to reinforce these new perspectives and possibilities for the Andalusian olive grove, the administration is now working to have it included in the World Heritage List (Sánchez, Ortega 2016).

\section{Final thoughts}

The heavy weight of tradition reduces the depth and speed of changes and, accordingly, the overview we have given is a minimally retouched productivist model that resists innovation if it is not a desperate reaction to the conjunctures of unfavourable prices, in the face of which, as a general rule, measures are adopted that are financially supported by the government and with the security that they have worked previously. Consequently, this latter aspect grants extraordinary importance to those who have behaved creatively or as pioneers, as paradigmatically has happened to those who have gambled on seeking higher quality, whose methods are now beginning to be imitated (although at a small scale) by the large cooperative enterprises that dominate most of the production (Rodríguez et al. 2017).

It is true that more and more elements of multifunctionality are recognised in this culture, but the dominant image is still that of olive groves conceived as an industry of oil production at low cost. The new plantations always follow a scheme in which thousands of irrigated shrubs are aligned and quickly enter into production with high yields. We have no doubt that the absence of attractive alternatives in the regional context suggests that the expansion in the area will continue in the coming years.

The political strategy to support the sector and the producing territories has opted, in line with the principles adopted by the European Union, for intelligent, sustainable and inclusive growth. It is worth highlighting, therefore, the priority (at least if we consider the budgetary allocations for this purpose in the current Rural Development Plan) of the economic amounts related to the management of the natural resources. In our opinion, the spread of sustainable production methods is urgent, at least in its softer version (integrated production), as a way to reconcile the healthiness of oil with the agro-ecosystems where it is produced, but also so that the landscape, tourism and patrimonial rhetoric might be more credible. A quick and, in our judgment, efficient formula for achieving this is to link the assistance payment (the basic payment scheme and green fee) to compliance.

Whatever new features acquire a greater weight and add unquestionable value to the product, one must not lose sight of the fact that the core feature will continue to be agriculture. Accordingly, two issues are critical: the proper management of water resources and positive discrimination in favour of the least productive olive groves. Marginal olive groves, provided they have not exceeded the ecological limits making it more appropriate to encourage their orderly replacement by forest vegetation, may be suitable for turning production spaces into landscapes of a heritage and environmental value, favouring the adoption of organic and even biodynamic methods, a novelty that has recently appeared within this diverse and contrasting monoculture.

\section{Acknowledgements}

This study is part of a wider research project entitled "Characterisation and perspectives of the olive monoculture in Jaén: its spatial and chronological formation, landscape-agronomic diversity and territorial immediate dynamics", which is funded by the Ministry of Economy, Innovation and Science of the Regional Government of Andalusia (SEJ - 1153, session 2012).

\section{References}

AEMO - Asociación Española de Municipios del Olivo, 2010. Aproximación a los costes del cultivo del olivo. Cuaderno de conclusiones del seminario AEMO. http://www.aemo.es/ get.php?pathext=descargas/Costes_AEMO.pdf.

Almstedt A., 2013. Post-productivism in rural areas: A contested concept. In: Lundmar L., Sandström C. (eds), Natural resources and regional development theory. Institutionen för geografi och ekonomisk historia, Umeå Universitet, Umeå: 8-22.

Anglés S., Veysseyre J., Cohen M., 2013. Appelations d'origine protégée oléicoles, terroires et territoires méditerranéens: une analyse comparative entre les appelations 
oléicoles en France et Andalousie. Sud-Ouest Européen, Revue géographique des Pyrénées et du Sud-Ouest 36: 123133.

Beaufoy G. 2001. The environmental impact of olive oil production in the European Union: Practical options for improving the environmental impact. http://ec.europa.eu/ environment/agriculture/pdf/oliveoil.pdf.

Belletti G., Canada J.S., Marescotti A., Vakoufaris H., 2015. Linking protection of geographical indications to the environment: Evidence from the European Union olive-oil sector. Land Use Policy 48: 94-106.

Berbel Vecino J., Giannocaro G., 2013. Economía de los olivares en Andalucía. In: Andalucía. El olivar. Grupo de Estudios Avanzados sobre Territorio y Medio Ambiente, Sevilla: 133-146.

Cohen M., Angles S., Marques C., Jimenez E.A., 2012. L'oliveraie entre espace productif et patrimoine paysager. Une comparaison Andalousie (Espagne) et Alpes du Sud (France). In: Luginbühl Y., Terrason D. (eds), Paysage et développment durable. Quae éditions, París: 143-155.

Consejo Oleícola Internacional, 2015. Estudio internacional sobre costes de producción del aceite de oliva. http://www. internationaloliveoil.org/ documents/index/1815-international-olive-oil-production-costs-study.

Evans N.J., 2001. Reflexiones en torno al modelo agropecuario productivista. In: García Pascual F. (ed.), El mundo rural en la era de la globalización: incertidumbres y potencialidades. Ministerio de Agricultura, Pesca y Alimentación, Madrid: 45-64.

Guzmán Álvarez J.R., 2005. Territorio y medio ambiente en el olivar andaluz. Sevilla. Consejería de Agricultura y Pesca de la Junta de Andalucía.

Junta de Andalucía, 2011. LEY 5/2011, de 6 de octubre, del olivar de Andalucía. Boletín Oficial de la Junta de Andalucía 205: 6-13.

Junta de Andalucía, 2014. Programa de desarrollo rural de Andalucía. Subprograma temático del sector del olivar. http:// www.juntadeandalucia.es/ export/ drupaljda/Subprograma $\% 20$ Tematico $\% 20 \mathrm{del} \% 20$ sector $\% 20 \mathrm{del} \% 20 \mathrm{oli}-$ var\%20Junio\%202015.pdf.

Ministerio de Agricultura, 1975. Inventario agronómico del olivar. II Provincia de Jaén.. Dirección General de la Producción Agraria, Madrid.

Moreno-Pérez O.M., 2013. Reproducing productivism in Spanish agricultural systems. Research in Rural Sociology and Development 19: 121-147.

Paniza Cabrera A., García Martínez P., Sánchez Martínez J.D., 2015. Análisis de la expansión del olivar en la provincia de Jaén a través de fuentes cartográficas (19562007). Anales de Geografía 35 (1): 119-137.

Parra López C., Sayadi Gmada S. (eds), 2009. Multifuncionalidad agraria, desarrollo rural y políticas públicas: nuevos desafíos para la agricultura. Junta de Andalucía, Sevilla.

Rastoin J.L., 2016. Redéployer la diète mediterranéenne par des systèmes alimentaires territorialisés. Journal Resolis 12: 72-82.
Rodríguez Cohard J.C., Parras Rosa M., 2011. The olive growing agri-industrial district of Jaén and the international olive oils cluster. The Open Geography Journal 4: 55-72.

Rodríguez Cohard J.C., Sánchez Martínez J.D., Gallego Simón V.J., 2017. The upgrading strategy of olive oil producers in southern Spain: origin, development and constraints. Rural Society 26(1): 30-47.

Ruiz Pulpón A.R., 2013. El viñedo en espaldera: nueva realidad en los paisajes vitivinícolas de Castilla-La Mancha. Boletín de la Asociación de Geógrafos Españoles 63: 249-270.

San Miguel Tabernero P., 2010. Evolución de las ayudas al olivar en España. In: Vilar J. et al. (eds), El patrimonio oleícola. Análisis desde la diversidad del conocimiento. Grupo de Desarrollo Rural de Sierra Mágina, Jaén: 313-353.

Sánchez Martínez J.D., Gallego Simón V.J., Araque Jiménez E., 2008. El monocultivo olivarero jiennense ¿del productivismo a la sostenibilidad? Boletín de la Asociación de Geógrafos Españoles 47: 245-270.

Sánchez Martínez J.D., Gallego Simón V.J., 2011. La nueva reconversión productiva del olivar jiennense: aproximación inicial a sus fundamentos y limitaciones. Cuadernos Geográficos 49: 95-121.

Sánchez Martínez J.D., Rodríguez Cohard J.C., Gallego Simón V.J., 2015. La PAC 2015-2020 y su influencia en los territorios andaluces de especialización oleícola. Comunicación presentada al XXXI Encuentro ARETHUSE. http://www.pe.uma.es/arethuse/.

Sánchez Martínez J.D., Ortega Ruiz A., 2016. El monocultivo olivarero jiennense: conformación histórica, valores patrimoniales y proyección cultural-turística. Cuadernos de Turismo 37: 377-402.

Scheidel A., Krausmann F., 2011. Diet, trade and land use: a socio-ecological analysis of the transformation of the olive oil system. Land Use Policy 28: 47-56.

Silva Pérez R., Fernández Salinas V., Molinero Hernando F., 2016. El carácter del paisaje como medio para la identificación de los valores patrimoniales del viñedo español. In: Ruiz Pulpón A.R. et al. (eds), Treinta años de Política Agraria Común en España. Agricultura y multifuncionalidad en el contexto de la nueva ruralidad. Asociación de Geógrafos Españoles, Ciudad Real: 900-915.

Van Broekhuizen R., Soldaat B., Oostindie H., Douwe van der Ploeg J., 2015. The distinctiveness of rural development practices in north-west Europe. Research in Rural Sociology and Development 22: 209-238.

Van der Ploeg G., Durand G., 2003. Multifunctional agriculture: a new paradigm for European agriculture and rural development. Ashgate, Hampshire: 37-53.

Velasco Gámez M., Vilar Hernández J., Puentes Poyatos R., 2012. Implicaciones de la PAC 2014-2020 para el sector oleícola. In: XIV Reunión Economía Mundial. http:// xivrem.ujaen.es/programa-2/viernes-1-de-juniode-2012.

Zambrana Pineda J.F., 2006. El sector primario andaluz en el siglo XX. Instituto de Estadística de Andalucía, Sevilla. 